\title{
E-cigarettes: knowledge and usage habits among dental patients
}

\author{
Diego Machado Ardenghi*; Kyla Tzupa ${ }^{* *}$; Lisa Rumpel**; Jay Hoover***; Renata Grazziotin-Soares****
}

\author{
* DDS, MA, MSc, Dip Prosthodontics [FRCD $(\mathrm{C})]$, \\ University of Florida, FL, USA \\ ** Dental Student, University of Saskatchewan, SK, Canada \\ *** DDS, Dip Periodontology, MSc, PhD, University of \\ Saskatchewan, SK, Canada \\ **** DDS, Dip Endodontics, MSc, PhD, University of \\ Saskatchewan, SK, Canada
}

Received January 13, 2020. Approved January 23, 2020.

\begin{abstract}
Electronic cigarettes (e-cigarettes) are increasingly popular in many countries and became a public health concern. In some places, such as, in Brazil, electronic smoking devices were banned from the market. Even though e-cigarettes are illegal in Brazil, it is important to emphasize the need to educate dental professionals regarding the potential hazards of vaping on the oral and systemic health. This study questioned Canadian dental patients about e-cigarettes, aiming to share information with dental professionals around the world regarding this contemporary issue. One hundred sixty-three (163) adult dental patients who attended a Canadian university dental clinic in the period February-May 2018 answered a closed-ended questionnaire to investigate their knowledge about e-cigarettes and their usage habits. Data was descriptively reported (frequencies and percentages). Only 7 (4.29\%) patients $(\geq 18$ years old) had never heard about e-cigarettes. Overall, patients believed that conventional cigarettes are more harmful to the general $(88.95 \%)$, and oral health $(91.41 \%)$, in comparison to the negative effects caused by e-cigarettes to the general (69.93\%), and oral health $(69.32 \%)$. Prosthodontic crowns and implants were cited as structures that might not be affected by e-cigarettes. Twenty-one (12.88\%) patients had already tried an e-cigarette (half of those were nonsmokers). The reasons to try e-cigarettes were: 'they help to quit smoking and they are a safer alternative to smoking'. The harmfulness of e-cigarettes compared to conventional cigarettes was pointed as: i) both types are equally harmful > ii) e-cigarettes are harmful, but not as bad as conventional cigarettes $>$ iii) e-cigarettes are more harmful. Patients were aware of the negative effects of e-cigarettes, but to a lesser degree when comparing their knowledge to conventional cigarettes. A few participants have already tried an e-cigarette and almost half of those were nonsmokers.
\end{abstract}

Descriptors: E-cigarettes. Dental Clinics. Education, Dental. 


\section{INTRODUCTION}

Electronic cigarettes (e-cigarettes) are increasingly popular in many countries (such as in Canada) and became a public health concern. Electronic smoking devices were banned by the health regulatory agencies from many countries. This ban was motivated by the lack of evidence regarding the alleged therapeutic properties and harmlessness of these products. Even though ecigarettes are illegal in Brazil, it is essential to emphasize the need to educate Dental professionals regarding the potential hazards of vaping on the oral and systemic health.

In Canada, e-cigarettes have become popular since their introduction in the North American market in the last decade ${ }^{1}$. According to the Canadian Tobacco, Alcohol and Drugs Survey, the number of Canadians aged 15 years and older who had ever tried an e-cigarette has gradually increased: $9 \%$ (2.5 million) in $2013 \leq$ $13 \%$ (3.9 million) in $2015 \leq 15 \%$ (4.6 million) in $2017^{2-4}$.

In Brazil, after ANVISA (the National Health Surveillance Agency) had banned ecigarettes from the market, many people criticized this action, claiming that these products could aid smoking cessation and could be less toxic than ordinary cigarettes ${ }^{5}$.

E-cigarettes are one of the many available devices named "ENDS" (electronic nicotine delivery systems) or "ESDs" (electronic smoking devices). They are battery-powered devices that aerosolize a solution ("e-liquid") containing nicotine, a mixture of chemicals that gives fruity flavors, and other additives such as propylene glycol and glycerin/glycerol. During the smoking act ("vaping"), an airflow sensitive device activates the cartridge causing the liquid within to vaporize, producing a smoke-like aerosol that is inhaled by the user ${ }^{6-9}$.

Formerly, e-cigarettes used to be advertised as a smoking cessation tool ${ }^{10}$ and were considered less harmful than conventional cigarettes by limiting exposure to combustible forms of tobacco. Also, they were marketed as a healthier and safer alternative to traditional cigarette smoking, providing health benefits to smokers who switched entirely to them ${ }^{11}$. More recently, a significant portion of e-cigarette business has been conducted on the internet, including company websites, blogs and social media (YouTube, Twitter and others). This has changed and expanded the focus of the 'e-cigarettes propaganda', that is now not only advertised as a tool for smoking cessation, or as a 'healthier' alternative to smoking, but also as a compelling and exciting recreational activity, whereby the person can create his/her own unique vaping experience with the use of different flavors, device modification, and vape tricks ${ }^{12}$.

The news coming from the media may influence patient's harm perceptions and use intentions concerning e-cigarettes ${ }^{13}$.

Up to date, there is a dearth of strong clinical evidence demonstrating the real effects of ecigarettes on human health. However, contemporary evidences have linked the use of ecigarettes with negative health consequences ${ }^{14,15}$ and may, in fact, not facilitate adult smokers to quit smoking at rates higher than smokers who do not use these products ${ }^{9,16}$.

The current literature has shown some effects of e-cigarettes on oral health, such as increased prevalence of three specific types of oral mucosal lesions (nicotine stomatitis, hairy tongue and angular cheilitis) among e-cigarettes users $^{17,18}$; and higher levels of pro-inflammatory cytokines, suggesting greater peri-implant inflammatory response ${ }^{19}$. In vitro studies found that e-cigarettes and other vapors devices may induce a lethal form of DNA damage that can result in chromosomal rearrangement and carcinogenesis ${ }^{20}$. Additionally, several incidents of trauma resulting from e-cigarettes explosion 
have been reported in the literature, for instance, burns to the thighs and hands ${ }^{21,22}$, damage to the anterior dentition (fractured teeth, avulsions, luxation), fracture of the premaxilla and the anterior nasal spine, lacerations to the upper lip, and injuries to labial mucosa, gingivae, tongue, hard palate, and facial skin ${ }^{23}$.

Recently, Bertoni et al. surveyed a sample of Brazilians aged 12-65 years old and showed that e-cigarette, narghile, and traditional cigarette prevalence rates were estimated at $0.43 \%, 1.65 \%$ and $15.35 \%$, respectively, corresponding to around 0.6 million e-cigarette users, 2.5 million narghile users and 23.5 million traditional cigarette users. Despite similarities, ecigarette/narghile users were younger and had higher socioeconomic status than traditional cigarette users ${ }^{24}$.

In 2012, a sample of 1,188 of Canadians youth and young adults (age 16-30 years) after viewing an image of an e-cigarette, answered questions regarding their perceptions and use habits. At that time, the awareness about ecigarettes was considered high, and $16 \%$ of the participants had tried e-cigarettes, with evidence of use among non-smokers ${ }^{25}$.

In 2015, 242 Canadians (aged 16-70 years) from Ottawa who purchased e-cigarettes or ecigarette-related supplies answered an online survey about perceptions of the benefits, harms, and risks of e-cigarette use. More than $80 \%$ indicated that quitting smoking was a significant reason to start using e-cigarettes and $60 \%$ stated that they intended to stop using e-cigarettes at some point. Most of the e-cigarette users perceived them as harmless ${ }^{26}$.

Considering the limited published data available on the use of e-cigarettes, the aim of this study was to investigate the knowledge and usage habits regarding e-cigarettes amongst adult patients attending a Dental school university clinic (University of Saskatchewan) in Canada. The preliminary results from this study will prompt future research regarding e-cigarettes and will act as a guide to implement actions, practice, and programs to reach and benefit the dental community and beyond.

\section{METHODOLOGY}

A hundred and sixty participants, from a convenience sample of patients, who attended the university dental clinic in the period of February $18^{\text {th }}$ to May $18^{\text {th }}, 2018$ answered the survey.

A closed-ended questionnaire was designed to investigate the patients' knowledge about ecigarettes and their usage habits. The questionnaire was previously tested in a pilot study using 20 adults (dental students and adults from the general public) who provided feedback for the researchers, aiming to improve the survey. The questionnaire had demographic and personal information questions (gender, age, ethnicity, occupation, education, reason for attending the dental clinic, and self-awareness about health), nine questions about the participant's knowledge regarding e-cigarettes (including questions on patient's assumptions about general and oral health damage) and eight questions about usage habits (including questions on conventional smoking and e-cigarettes). This study received approval by the University Research Ethics Board (Beh-REB ID: 17-264).

All adult patients $(\geq 18$ years old), who attended the clinic during the 3-month-period when the survey was conducted, were invited to participate. They received information about the nature of the study and were advised that if they declined to join, it would not jeopardize their treatment at the clinic. Patients who agreed to participate anonymously answered the questionnaire in the reception area, before the dental consultation. An informed consent was implied upon completion and returning the questionnaire.

Data were recorded in Microsoft Excel 
(Microsoft ${ }^{\circledR}$ Excel $^{\circledR}$ for Mac 2011, Version 14.7.7) and descriptively analyzed (frequencies and percentages).

\section{RESULTS}

Sample characteristics are reported in table 1. Demographics showed that the majority of the participants were females $(84 / 163,51.53 \%), 60$ years-old or more $(106 / 163,65.03 \%)$, Caucasian (147/163, 90.18\%), educated but without university degree $(115 / 163,70.55 \%)$, retired $(95 / 163,58.28 \%)$, and preferred not to answer the question about income $(80 / 163,49.07 \%)$. More detailed description of the percentage of males vs. females by age group is shown in figure 1. The majority of the participants sought treatment for prosthodontics appointments (71/163, 43.55\%) and considered their overall health status as good (92/163, 56.44\%).

Regarding the knowledge about conventional cigarettes, the majority of the participants perceived that smoking regular cigarettes was harmful to the body (overall health) $(145 / 163,88.95 \%)$, and to the mouth (oral health) (149/163, 91.41\%) (table 2). Participants pointed many effects resulting from smoking, as follows (in descending order): lung cancer $>$ mouth and/or throat cancer $>$ gum disease $>$ slower wound healing time.

Concerning the knowledge about ecigarettes, the results were as follows: 149/163 participants $(91.41 \%)$ were aware about ecigarettes, while only $7 / 163(4.29 \%)$ had never even heard of them, and 7/163 (4.29\%) did not respond the question. The source of information about e-cigarettes were (in descending order): advertisements (TV, radio, newspaper) $>$ internet (online adds and social media) > friends and family $>$ other (such as have seen people on the streets using it or have seen information on information booths and kiosks) > doctor`s office.

The majority of the participants thought that e-cigarettes might be damaging to the body (overall health) $(114 / 163,69.93 \%)$, as well as to the mouth (oral health) 113/163 (69.32\%). Numerous systemic implications caused by the use of e-cigarettes were noted (in descending order): lung cancer $>$ mouth cancer $>$ gum disease $>$ slower wound healing time. Also, participants were given the choice to indicate aspects that might be not be affected by e-cigarettes. Slower wound healing time was the most specified. In addition, participants pointed that injuries caused by e-cigarettes might affect (in descending order): gums $>$ teeth supporting dentures and/or bridges > dental implants > crowns. Several participants believed that crowns and implants are not negatively affected by e-cigarettes.

Regarding the use of e-cigarettes, 139/163 $(85.27 \%)$ participants indicated never having tried, while $21 / 163(12.88 \%)$ had already tried, and $3 / 163(1.84 \%)$ participants did not answer the question. The reasons for trying e-cigarettes are shown in figure 2. People who had never tried ecigarettes responded to a question about the reason for not trying (figure 2).

Concerning smoking conventional cigarettes, 96/163 (58.89\%) participants had previously smoked at least once, while 22/163 $(13.49 \%)$ were currently smokers. The current smokers recorded the period of time that they have been smoking: $\geq 10-\leq 30$ years, $8 / 22(36.36 \%)$; $>30$ - $\leq 40$ years, $3 / 22$ (1.84\%); > 40 - $\leq 60$ years, $8 / 22$ (36.36\%). Other responses were: "many years", 1/22 (4.54\%); 2 years, 1/22 (4.54\%);-and $1 / 22(4.54 \%)$ participant did not answer the question.

Approximately $82 \%$ of the 22 people who were current smokers had tried to quit the habit, while only 4/22 (18.18\%) participants had never tried it. The majority of the current smokers $17 / 22$ (77.27\%) want to still quit smoking, and $4 / 22$ $(18.18 \%)$ smokers do not want to quit. One person $(1 / 22,4.54 \%)$ did not answer this question. 
Table 1. Sample ( $n=163)$ characteristics: demographics and personal topics

\begin{tabular}{|c|c|}
\hline Sample Characteristic & $\mathbf{n}(\%)$ \\
\hline \multicolumn{2}{|l|}{ Gender } \\
\hline Females & $84(51.53 \%)$ \\
\hline Males & $77(47.23 \%)$ \\
\hline No answer & $2(1.47 \%)$ \\
\hline \multicolumn{2}{|l|}{ Age } \\
\hline$\leq 39$ & $12(7.36 \%)$ \\
\hline$\geq 40-\leq 59$ & $43(26.3 \%)$ \\
\hline$\geq 60-\leq 70$ & $52(31.9 \%)$ \\
\hline$\geq 71$ & $54(33.12 \%)$ \\
\hline \multicolumn{2}{|l|}{ Race } \\
\hline American Indian or Alaska Native (aboriginal) & $1(0.61 \%)$ \\
\hline Asian & $5(3.06 \%)$ \\
\hline African American or Black & $1(0.61 \%)$ \\
\hline Native Hawaiian or Other Pacific Islander & 0 \\
\hline White & $147(90.18 \%)$ \\
\hline No answer & $3(1.84 \%)$ \\
\hline \multicolumn{2}{|l|}{ Education } \\
\hline No education & 0 \\
\hline Secondary school, High school, technical training, incomplete university & $90(55.2 \%)$ \\
\hline Other (certificates or current studying) & $25(15.33 \%)$ \\
\hline University degree completed & $29(17.79 \%)$ \\
\hline \multicolumn{2}{|l|}{ Occupation } \\
\hline Currently working & $68(41.71 \%)$ \\
\hline Retired & $95(58.28 \%)$ \\
\hline \multicolumn{2}{|l|}{ Income (money left over at the end of the month) } \\
\hline More than enough & $39(23.92 \%)$ \\
\hline Just enough & $29(17.79 \%)$ \\
\hline Not enough & $15(9.20 \%)$ \\
\hline Prefer not to answer & $80(49.07 \%)$ \\
\hline \multicolumn{2}{|l|}{ Reason to visit the dental school (chief complaint) } \\
\hline Physical examination (checkup) & $24(14.72 \%)$ \\
\hline Dental prophylaxis (teeth cleaning) & $11(8.08 \%)$ \\
\hline Operative dentistry (fillings, broken fillings, broken tooth) & $33(20.24 \%)$ \\
\hline Prosthodontics (removable dentures, bridge or crowns, implants) & $71(43.55 \%)$ \\
\hline Oral surgery (tooth extraction) & $6(3.68 \%)$ \\
\hline Endodontics (root canal treatment) & $6(3.68 \%)$ \\
\hline Emergency (pain) & $2(1.22 \%)$ \\
\hline Other reasons & $8(4.90 \%)$ \\
\hline No answer & $2(1.22 \%)$ \\
\hline \multicolumn{2}{|l|}{ Self-reported overall health status } \\
\hline Excellent & $19(11.65 \%)$ \\
\hline Good & $92(56.44 \%)$ \\
\hline Average & $50(30.67 \%)$ \\
\hline Poor & $2(1.22 \%)$ \\
\hline
\end{tabular}




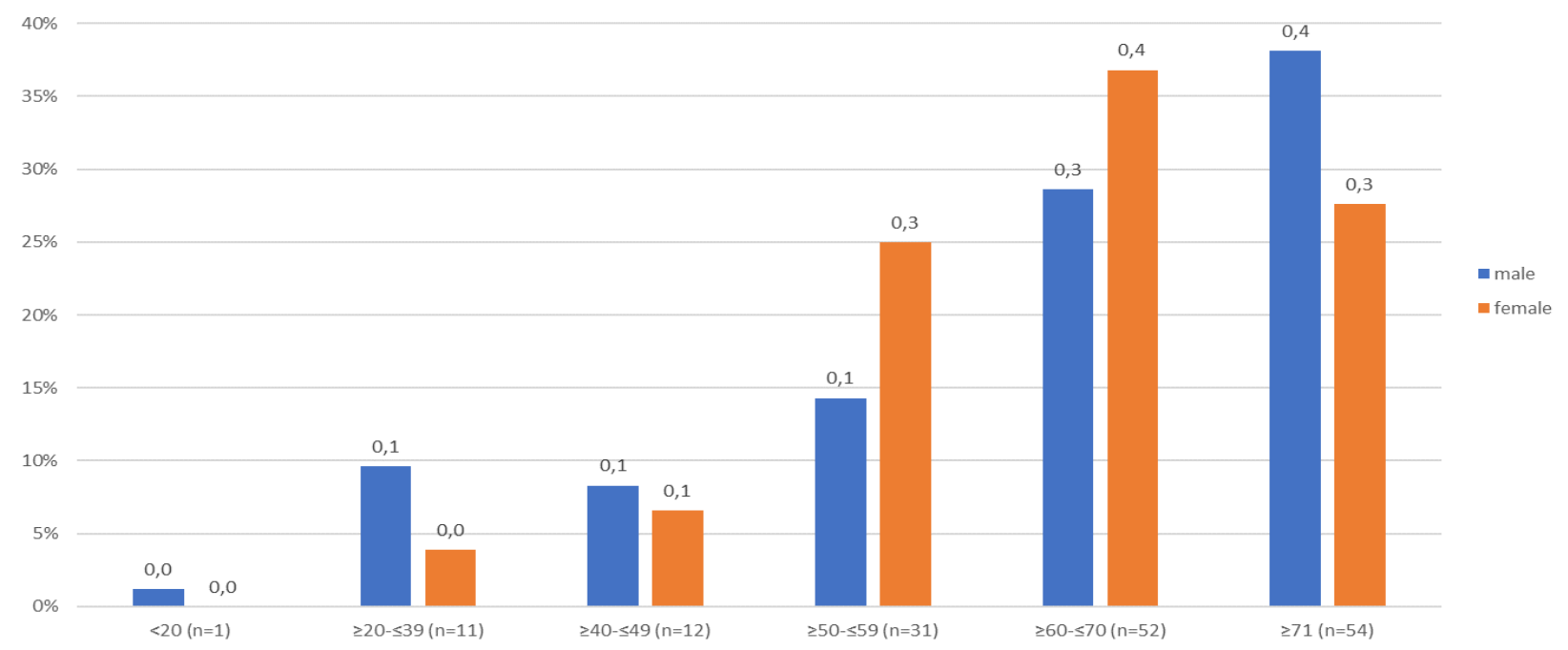

Figure 1. Percentage of males vs. females by age group

Table 2. Participants' knowledge about the effects caused by smoking

\begin{tabular}{|c|c|c|c|}
\hline & & $\begin{array}{l}\text { Conventional } \\
\text { cigarettes }\end{array}$ & e-cigarettes \\
\hline \multirow{3}{*}{$\begin{array}{l}\text { Are they damaging to } \\
\text { the body (overall } \\
\text { health)? }\end{array}$} & Yes & $145(88.95 \%)$ & $114(69.93 \%)$ \\
\hline & No & $7(4.29 \%)$ & $26(15.95 \%)$ \\
\hline & I do not know or No answer & $11(6.74 \%)$ & $23(14.11 \%)$ \\
\hline \multirow{3}{*}{$\begin{array}{l}\text { Are they damaging to } \\
\text { the mouth (oral health)? }\end{array}$} & Yes & $149(91.41 \%)$ & $113(69.32 \%)$ \\
\hline & No & $4(2.45 \%)$ & $24(14.72 \%)$ \\
\hline & I do not know or No answer & $10(6.13 \%)$ & $26(15.95 \%)$ \\
\hline
\end{tabular}

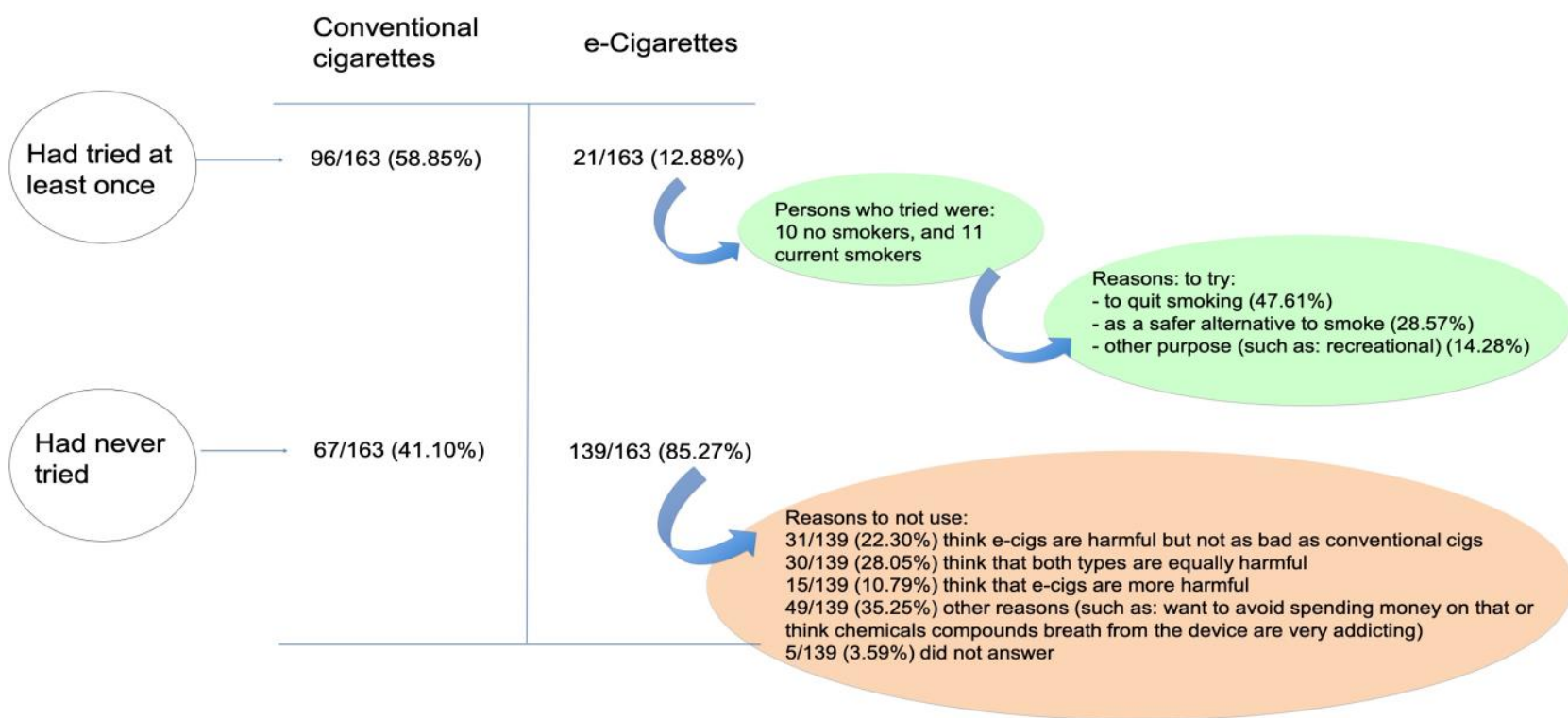

Figure 2. Usage habits of conventional and electronic cigarettes 
Current conventional cigarettes smokers, in addition to cigarettes, had also used e-cigarettes for the following periods: 1 to 5 years $(3 / 22$, $13.63 \%)$; some months $(5 / 22,22.72 \%)$; or for only a few days $(10 / 22,45.45 \%)$.

Some of the current smokers did not realize that e-cigarettes could help them quit smoking conventional cigarettes $(8 / 22,36.36 \%)$, while $12 / 22(54.54 \%)$ thought that e-cigarettes could be helpful. Two participants $(2 / 22,9.09 \%)$ did not answer this question.

\section{DISCUSSION}

Knowledge concerning e-cigarettes was high among participants, since $91.41 \%$ of people had already heard about the devices and believed that e-cigarettes are damaging to the general $(69.93 \%)$ and oral $(69.32 \%)$ health. Only a small percentage of the subjects had actually used them, at least once (12.88\%), and approximately half of them were non-smokers. The majority of the current smokers desired to quit smoking $(77.27 \%)$ and thought e-cigarettes could help in smoking cessation $(54.54 \%)$.

Most of those who responded to the current survey comprised of seniors over the age of 65 years and retirees. With respect to dental treatment needs, restorative and prosthodontics were identified as the most common. Traditionally, patients`age might reflect the need for oral rehabilitation treatment ${ }^{27}$. In our study $43.55 \%$ sought dentures, bridges, and crowns.

Our findings showed that the respondents obtained information about e-cigarettes from the media, including commercial advertisements and the internet, sources that may be deemed to be not always reliable. Although the majority of respondents were conscious of the damages caused by smoking, they were less informed about the potential detrimental effects that ecigarettes have on general and oral health. This may be because e-cigarettes are relatively new on the market and evidences pertaining to any detrimental effects have still to reach the public ${ }^{9}$. Furthermore, information available online is mostly dominated by the vaping industry and could be biased ${ }^{12}$.

Participants thought that e-cigarettes might not be damaging to crown and implants. In fact, there is an emerging body of evidence indicating that vaping not only affects oral mucosa tissues $^{20,11}$, but also artificial oral structures, such as crown, bridges, and implants ${ }^{19,21,22}$. This flawed impression could be attributed to some factors: i) the general lack of reliable knowledge concerning effects of vaping; ii) some patients were attending their first appointment and may not have received reliable information about the impact vaping has on fixed prosthesis, and iii) a possible lack of standardized information provided by staff, faculty members and dental students regarding e-cigarettes.

The need to educate dental professionals regarding the potential hazards of vaping on the oral and systemic health has been shown in a recent study ${ }^{28}$. The Canadian Dental Association's position on "Tobacco Products, Smoking Cannabis, and Vaping" is that, based on current evidence, dentists must review the known and potential risks on exposure and consumption of those products with their patients, and recommend measures that promote cessation and reduce the harm caused by using these substances $^{29}$. The 'Brazilian Curricular Guidelines for Undergraduate Studies in Dentistry ${ }^{\prime 30}$ is clear in regard that dental students must be able to develop health prevention, promotion, protection and rehabilitation actions, individually and collectively. This means that dental students must possess knowledge about ecigarettes, in order to educate patients and provide them alternatives for smoking cessation. Therefore, it is prudent for any dental professional, either Brazilians or internationals, 
to be familiar with smoking cessation techniques addressed to not only to conventional cigarettes but also to e-cigarettes, and other vaping devices such as vape-pens and advanced personal vaporizes.

The majority of the participants thought that e-cigarettes help in smoking cessation, and many have been smoking e-cigarettes for a long time. This opinion seems to be a consensus among participants. However, this "common knowledge" about smoking cessation is based on inconclusive evidence ${ }^{28,31}$. The available evidences indicate that vaping negatively affect different biological systems (pulmonary, immune, central nervous and others); the vapor condensation of an e-cigarette appeared to cause pro-inflammatory effects on human alveolar macrophages; propylene-glycol (an agent used in e-cigarettes) can cause respiratory irritation and may increase the risk of asthma; glycerol can cause lipoid pneumonia when inhaled; nicotine is addictive; some aerosols contain carcinogenic substances. Other potential public health issues are the possible skin reactions to dermal contact with e-liquids, home-blending risks, accidental potential fire hazards and explosion, and the need of specialized waste management to avoid environmental impacts ${ }^{32}$. Unfortunately, the above mentioned long and short-term effects of vaping are not widely known to the general public at the present time.

Another finding of interest in the present study is that, amongst those who indicated that they had tried e-cigarettes at least once, half were non-smokers (they had never smoked a conventional cigarette). In this sense, the use of e-cigarettes may be a gateway to start smoking or even to start using other types of $\operatorname{drugs}^{33,34}$. Recent evidences have proved that the new use of one tobacco product may catalyze subsequent use of other products through cross-product changes in perceptions (perceived harm) and susceptibility (curiosity and willingness) ${ }^{35}$. In a large cohort of Canadian secondary school students, e-cigarettes were strongly associated with cigarette smoking behavior, including smoking initiation at follow up ${ }^{36}$.

The limitations of this study include the sample comprised of an older group of subjects attending a university-based dental clinic and may not, therefore, be representative of a general adult population, hence producing less desirable external validity. Also, as vaping is more evident among youth and young adults explains the relatively low percentage of users in the present sample. Future research will focus on young patients, which is the major public health concern about e-cigarettes and vaping. Additionally, selfreported responses are subjected to reporting bias and error, which could lead to over or underreporting due to misinterpretation of the questions. Nevertheless, within the constraints of the limitations of this study, the present findings may be useful to compare the current knowledge and use habits towards e-cigarettes among dental patients from other universities in Canada and overseas. As the scientific literature is currently building new evidences on the potential adverse effects of e-cigarettes, it is the responsibility of oral health professionals to keep abreast with such research and educate our patients about the risks associated with the use of these products.

\section{CONCLUSION}

This study demonstrated that adult dental patients were knowledgeable about e-cigarettes and obtained information about smoking products from the media, including online social media. Although these patients were aware of adverse effects of using e-cigarettes, their overall knowledge base was low in comparison to their knowledge about conventional cigarettes. Only a few participants had already tried an e-cigarette and half of those were non-smokers. 


\section{ACKNOWLEDGMENTS:}

The authors would like to express their special appreciation and thanks to all those who participated in the study and to Dr. Lim (Professor of Community Health \& Epidemiology College of Medicine, University of Saskatchewan), for assistance with the data analysis.

\section{RESUMO}

Cigarro eletrônico: conhecimento e hábito de uso entre pacientes odontológicos

Cigarros eletrônicos são cada vez mais populares em muitos países (como por exemplo, no Canadá) e se tornaram um problema de saúde pública. Em alguns lugares, como no Brasil, os aparelhos eletrônicos para fumar foram banidos do comércio. Apesar de os cigarros eletrônicos serem ilegais no Brasil, é importante que se enfatize a necessidade de educar os profissionais da odontologia em relação aos perigos potenciais do 'vaping' para a saúde oral e sistêmica. Este estudo questionou pacientes de uma faculdade de odontologia do Canadá sobre cigarros eletrônicos, com o objetivo de informar profissionais da odontologia a respeito deste problema contemporâneo. Cento e sessenta e três (163) pacientes adultos que procuraram atendimento na clínica dentária de uma faculdade de odontologia do Canadá no período de fevereiro a maio de 2018 responderam um questionário fechado objetivando investigar o conhecimento dos pacientes sobre cigarros eletrônicos e os hábitos de uso. Os dados foram descritivamente reportados (frequências e percentagens). Somente $7(4,29 \%)$ pacientes $(\geq$ 18 anos) nunca tinham ouvido falar sobre cigarros eletrônicos. De uma forma geral, os pacientes acreditam que os cigarros convencionais são mais prejudiciais à saúde geral $(88.95 \%)$ e oral $(91.41 \%)$, em comparação com os efeitos negativos causados pelos cigarros eletrônicos para a saúde geral $(69.93 \%)$ e oral $(69.32 \%)$. Coroas de próstese e implantes dentários foram citados como as estruturas que talvez não sejam afetadas pelos cigarros eletrônicos. Vinte e um $(12,88 \%)$ pacientes já tinham fumado um cigarro eletrônico (metade destes eram não fumantes). As razões para fumar cigarro eletrônico foram: "eles ajudam a parar de fumar e são uma alternativa segura ao cigarro". A nocividade dos cigarros eletrônicos comparada aos cigarros convencionais foi citada como: i) ambos são igualmente prejudiciais > ii) cigarros eletrônicos são prejudiciais, mas não tanto quanto os cigarros convencionais > iii) cigarros eletrônicos são mais prejudiciais. Os pacientes estavam cientes dos efeitos negativos causados pelos cigarros eletrônicos, mas em um grau menor quando comparado com o conhecimentos que tinham sobre os efeitos dos cigarros convencionais. Poucos participantes já tinham fumado um cigarro eletrônico e a metade destes eram não-fumantes.

Descritores: Cigarro eletrônico. Clínicas Odontológicas. Ensino Odontologico.

\section{REFERENCES}

1. Volesky KD, Maki A, Scherf C, Watson LM, Cassol E, Villeneuve PJ. Characteristics of ecigarette users and their perceptions of the benefits, harms and risks of e-cigarette use: survey results from a convenience sample in Ottawa, Canada. Health Promot Chronic Dis Prev Can. 2016;36(7):130-8.

2. CTADS - Canadian Tobacco, Alcohol and Drugs Survey, summary results of 2013. [Cited: Jan. 22, 2020]. Available at: https://www.canada.ca/en/health-canada/ services/canadian-tobacco-alcohol-drugssurvey/2013-summary.html.

3. CTADS - Canadian Tobacco, Alcohol and Drugs Survey, summary results of 2015. [Cited: Jan. 22, 2020]. Available at: https://www.canada.ca/en/health-canada/ services/canadian-tobacco-alcohol-drugssurvey/2015-summary.html.

4. CTADS - Canadian Tobacco, Alcohol and Drugs Survey, summary results of 2017. [Cited: Jan. 22, 2020]. Available at: https://www.canada.ca/en/health-canada/ 
services/canadian-tobacco-alcohol-drugssurvey/2017-summary.html.

5. Silva ALOD, Moreira JC. The ban of electronic cigarettes in Brazil: success or failure? Cien Saude Colet. 2019;24(8):301324.

6. Bertholon JF, Becquemin MH, AnnesiMaesano I, Dautzenberg B. Electronic cigarettes: a short review. Respiration. 2013;86(5):433-8.

7. Marcham CL, Springston JP. E-Cigarettes: a Hazy Hazard. Prof. Safety 2017;62:46-51.

8. Drope J, Cahn Z, Kennedy R, Liber AC, Stoklosa M, Henson R, et al. Key issues surrounding the health impacts of electronic nicotine delivery systems (ENDS) and other sources of nicotine. CA Cancer J Clin. 2017;67(6):449-71.

9. Sultan AS, Jessri M, Farah CS. Electronic nicotine delivery systems: Oral health implications and oral cancer risk. J Oral Pathol Med. 2018. [Cited: Jan. 22, 2020]. Available at: https://onlinelibrary.wiley. com/doi/abs/10.1111/jop.12810.

10. Hartmann-Boyce J, Begh R, Aveyard P. Electronic cigarettes for smoking cessation. BMJ. 2018;360:j5543.

11. Farsalinos KE, Polosa R. Safety evaluation and risk assessment of electronic cigarettes as tobacco cigarette substitutes: a systematic review. Ther Adv Drug Saf. 2014;5(2):67-86.

12. McCausland K, Maycock B, Leaver T, Jancey J. The Messages Presented in Electronic Cigarette-Related Social Media Promotions and Discussion: Scoping Review. J Med Internet Res. 2019;21(2): e11953.

13. Wackowski OA, Sontag JM, Hammond D. Youth and young adult exposure to and perceptions of news media coverage about ecigarettes in the United States, Canada and England. Prev Med. 2019;121:7-10.
14. Grana R, Ling P. "Smoking revolution": a content analysis of electronic cigarette retail websites. Am J Prev Med. 2014;46(4):395403.

15. Alzahrani T, Pena I, Temesgen N, Glantz SA. Association between electronic cigarette use and myocardial infarction. Am $\mathrm{J}$ Prev Med. 2018;55(4):455-61.

16. Weaver SR, Huang J, Pechacek TF, Heath JW, Ashley DL, Eriksen MP. Are electronic nicotine delivery systems helping cigarette smokers quit? Evidence from a prospective cohort study of U.S. adult smokers, 20152016. PLoS One. 2018;13(7):e0198047.

17. Farsalinos KE, Romagna G, Tsiapras D, Kyrzopoulos S, Voudris V. Characteristics, perceived side effects and benefits of electronic cigarette use: a worldwide survey of more than 19,000 consumers. Int J Environ Res Public Health. 2014; 11(4):4356-73.

18. Bardellini E, Amadori F, Conti G, Majorana A. Oral mucosal lesions in electronic cigarettes consumers versus former smokers. Acta Odontol Scand. 2018;76(3):226-8.

19. ArRejaie AS, Al-Aali KA, Alrabiah M, Vohra F, Mokeem SA, Basunbul G, Alrahlah A, Abduljabbar T. Proinflammatory cytokine levels and peri-implant parameters among cigarette smokers, individuals vaping electronic cigarettes, and non smokers. J Periodontol. 2019;90(4):367-74.

20. Califano J, van der Riet P, Westra W, et al. Genetic progression model for head and neck cancer: implications for field cancerization. Cancer Res. 1996;56(11) :2488-92.

21. Serror K, Chaouat M, Legrand MM, Depret F, Haddad J, Malca N, Mimoun M, Boccara D. Burns caused by electronic vaping devices (e-cigarettes): A new classification proposal based on mechanisms. Burns. 2018;44(3):544-8.

22. Harshman J, Vojvodic M, Rogers AD. Burns 
associated with e-cigarette batteries: A case series and literature review. CJEM. 2018;20(S2):S20-S28.

23. Brooks JK, Kleinman JW, Brooks JB, Reynolds MA. Electronic cigarette explosion associated with extensive intraoral injuries. Dent Traumatol. 2017;33(2):149-52.

24. Bertoni N, Szklo A, Boni R, Coutinho C, Vasconcellos M, Nascimento Silva $\mathrm{P}$, de Almeida LM, Bastos FI. Electronic cigarettes and narghile users in Brazil: Do they differ from cigarettes smokers? Addict Behav. 2019;98:106007.

25. Czoli CD, Hammond D, White CM. Electronic cigarettes in Canada: prevalence of use and perceptions among youth and young adults. Can J Public Health. 2014;105(2):e97-e102.

26. Volesky KD, Maki A, Scherf C, Watson LM, Cassol E, Villeneuve PJ. Characteristics of ecigarette users and their perceptions of the benefits, harms and risks of e-cigarette use: survey results from a convenience sample in Ottawa, Canada. Health Promot Chronic Dis Prev Can. 2016;36(7):130-8.

27. Yoon MN, Ickert C, Slaughter SE, Lengyel C, Carrier N, Keller H. Oral health status of long-term care residents in Canada: Results of a national cross-sectional study. Gerodontology. 2018;35(4):359-64.

28. Carreras-Presas CM, Naeim M, Hsiou D, Somacarrera Pérez ML, Messadi DV. The need to educate future dental professionals on E-cigarette effects. Eur J Dent Educ. 2018;22(4):e751-e758.

29. CDA (Canadian Dental Association) on Tobacco Products, Smoking Cannabis and Vaping. CDA Board of Directors, Approved February 2005, Revised October 2018. [Cited: Jan. 22, 2020]. Available at: https://www.cda-adc.ca/en/about/position statements/tobaccocannabisproducts/.
30. Conselho Nacional de Educação. Câmara de Educação Superior. Resolução CNE/CES 3, de 19 de fevereiro de 2002. Diretrizes Curriculares Nacionais do Curso de Graduação em Odontologia. [Cited: Jan. 22, 2020].Available at: http://portal.mec.gov.br/ cne/arquivos/pdf/CES032002.

31. Grana R, Benowitz N, Glantz SA. Ecigarettes: a scientific review. Circulation. 2014;129(19):1972-86.

32. Papaefstathiou E, Stylianou M, Agapiou A. Main and side stream effects of electronic cigarettes. J Environ Manage. 2019;238:107.

33. Choi K, Forster JL. Beliefs and experimentation with electronic cigarettes: a prospective analysis among young adults. Am J Prev Med. 2014;46(2):175-8.

34. Roditis M, Delucchi K, Cash D, HalpernFelsher B. Adolescents' perceptions of health risks, social risks, and benefits differ across tobacco products. J Adolesc Health. 2016;58(5):558-66.

35. Chaffee BW, Cheng J. Tobacco product initiation is correlated with cross-product changes in tobacco harm perception and susceptibility: Longitudinal analysis of the Population Assessment of Tobacco and Health youth cohort. Prev Med. 2018; 114:72-8.

36. Hammond D, Reid JL, Cole AG, Leatherdale ST. Electronic cigarette use and smoking initiation among youth: a longitudinal cohort study. CMAJ. 2017;189 (43):E1328-E1336.

\section{Correspondence to:}

Renata Grazziotin-Soares

e-mail: regrazziotin@gmail.com

University of Saskatchewan College of Dentistry

307-105 Wiggins Road

Saskatoon, SK Canada S7N 5E4 